Uşak Üniversitesi Sosyal Bilimler Dergisi

$2014,7 / 3$

\title{
Anne Kişiliği ve Çocuğun Mizaç Özelliği*
}

\author{
Abide Güngör AYTAR** \\ Ayşe B. AKSOY"** \\ Nazan KAYTEZ
}

\section{Özet}

Araştırmada annelerin kişilik özellikleri ve çocukların mizaçlarını etkileyen değişkenlerin belirlenmesi ve annenin kişiliği ile çocukların mizaçları arasındaki ilişkinin incelenmesi amaçlanmıştır. Araştırmaya Ankara ili Sincan ilçesinde bulunan özel anaokuluna devam eden dört-beş yaş arasındaki çocukların anneleri alınmıştır. Veri toplama aracı olarak annelerin ve çocukların sosyodemografik özelliklerini belirmek için araştırmacı tarafından hazırlanan "Genel Bilgi Formu", çocukların mizaçlarını belirlemek için "Çocuklar için Kısa Mizaç Ölçeği" ve annelerin kişilik özelliklerini belirlemek için "Sıfatlara Dayalı Kişilik Testi" kullanılmıştır. Araştırmada homojen dağılım gösteren veriler için "t-Testi", homojen dağılım göstermeyen veriler için "Mann-Whitney U testi", "Kruskall Wallis Testi" ve annenin kişilik özelliği ile çocuğun mizacı arasındaki ilişkiyi incelemek için de "Pearson Korelâsyon Katsayısı Önemlilik Testi" kullanılmıştır. Araştırma sonucunda; doğum sırası değişkeninin çocukların mizaçlarında yaş ve öğrenim düzeyi değişkenin ise annelerin kişiliklerin özelliklerinde anlamlı bir farklılığa neden olduğu belirlenmiştir $(\mathrm{p}<.05)$. Araştırmada ayrıca annelerin kişilikleri ile çocukların mizaçları arasındaki ilişkinin pozitif yönde anlamlı olduğu bulunmuştur.

Anahtar kelimeler: Anne, Çocuk, Mizaç, Kişilik.

** Prof. Dr., Gazi Üniversitesi Mesleki Eğitim Fakültesi Çocuk Gelişimi ve Eğitimi Bölümü

*** Doç. Dr., Gazi Üniversitesi Mesleki Eğitim Fakültesi Çocuk Gelişimi ve Eğitimi Bölümü

***** Öğr. Gör., Çankırı Karatekin Üniversitesi Sağlık Yüksekokulu Çocuk Gelişimi Bölümü 


\title{
Mothers Personality and Feature Temperament of Their Child
}

\begin{abstract}
The purpose of the study is to examine the relationship between mother's personality and temperament of children and determining variables which affect personality characteristics of mothers and temperament of the children's. Mothers of children between the ages 4-5 in the private pre-school located in the county Sincan of Ankara were included in the study (n:110). As data collection tool was used to determine sociodemographic characteristics of mothers and children "General Information Form" prepared by the researcher, the temperament of children "Short Temperament Scale for Children" and the personality characteristics of the mother "Based on Attributes Personality Test". In the research for the data, showing homogeneous distribution "t-Test" was used; for the data, not showing a homogeneous distribution "Mann-Whitney U test" and "KruskalWallis Test" were used and in order to examine the relationship between the mother's personality characteristics and the child's temperament "Pearson Correlation Coefficient Significance Test" was used. As a result, in children's temperament of the birth order variables, in mother's personality characteristics of the age and education level variables were determined to cause a significant difference $(\mathrm{p}<.05)$. In addition, in this study the relationship between children's temperament and mothers' personalities were found positively significant.
\end{abstract}

Key Words: Mother, Child, Temperament, Personality.

\section{Giriş}

Kişilik, mizaç ve karakter kavramları sıklıkla birbirine karıştırılmaktadır. Kişilik kavramı yıllarca farklı biçimlerde ele alınmış ve farklı zamanlarda farklı düşünce akımları ortaya çıkmıştır. Günümüzde kişilik kuramları var olsa da, kişiliğin hâlâ hemfikir olunmuş bir tanımı bulunmamaktadır (Altıntaş, 2009; Arsan, 2010). Freud'a göre kişilik id, ego, ve super ego'nun birleşimidir. Yörükoğlu'na (2007) göre kişilik kalıtımla getirilen özellikler ile çevrenin kişiye kazandırdığı özelliklerin tümüdür. Psikologlara göre ise kişilik, bir insanın ilgi, tutum, yetenek, konuşma tarzı, dış görünüş ve çevreye uyum biçimini kapsayan kendi içinde süreklilik gösteren bir bütündür. Karakter kişiye özgü davranışların bütünü olup, insanın bedensel, duygusal ve zihinsel etkinliğine çevrenin verdiği değerdir (Yavuzer, 2006). Bireyin karakteri, kişisel özelliklerle, içinde yaşanılan 
çevrenin değer yargılarından oluşmaktadır. Bu değer yargılarını benimseyip benimsememe, karakteri oluşturmaktadır. Karakter, kişilik ve içinde yaşanılan çevrenin değer yargıları ile birlikte yorumlanmaktadır ve zamanla değişebilecek özelliğe sahiptir. Aile, okul ve diğer sosyal çevre içinde geçirilen sosyal yaşantılar sonucu gelişmeye ve biçimlenmeye başlamaktadır (Neal ve ark. 2007, Yağmurlu ve ark. 2005). Kişiliğin diğer bir parçası olan mizaç ise günlük hayatta çok sık kullanılmasına rağmen tanımlanması oldukça zor olan bir kavramdır. Mizaç genel olarak çocuğun dünyayı algılayışını ve yaklaşımını yapılandıran doğuştan getirdiği özellikler şeklinde tanımlanmaktadır. Örneğin, çabuk kızmak, öfkelenmek, sıkılgan, neşeli, içedönük veya dışadönük olmak mizaçla ilgili özelliklerdir (Yavuzer, 2006; Şahinoğlu, 2010).

Dünyaya gelen her bebek anne ve babası başta olmak üzere aile geçmişinin genetik kazanımları ile doğmaktadır. Mizacın gelişiminde kalıtım önemli olduğu için anne-babanın mizacı ile çocuğun mizacı birbirine benzeyebilmektedir. Örneğin, içedönük mizaca sahip annelerin çocukları içedönük bir mizaca, sinirli annelerin çocukları da sinirli bir mizaca sahip olabilmektedir. Öç vd. (2009) çalışmalarında nevrotik kişilik özelliğine sahip annelerin çocuklarının da nevrotik kişilik özelliği taşıdığını belirlemişlerdir. Muris ve Ollendick (2005) çalışmalarında ise annenin kaygılı bir yapıya sahip olmasıyla çocuğunun kaygılı bir yapıya sahip olması arasında anlamlı bir ilişki bulmuşlardır.

Çocukların mizaç özellikleri ilk defa Thomas ve Chess (1956) tarafından araştırılmış ve çalışmanın sonuçları “New York Boylamsal Çalışması" adıyla 1977 yılında yayınlanmıştır. Bu çalışmaya göre çocuklarda 9 farklı mizaç boyutu bulunmaktadır. Bunlar, aktivite düzeyi, ritmiklik, çekingenlik, uyumluluk, tepkisellik, uyarılma eşiği, huyların niteliği, dikkat dağınıklığı ve dikkat süresi ve devamlılıktır (Akt: Grist ve McCord, 2010). Çocuklarda mizacı araştıran bir başka araştırmacı Cloninger (1997) ise mizacın yenilik arayışı, zarardan kaçınma, ödül bağımlılı̆̆ ve sebat etme gibi boyutlardan oluştuğunu belirtmiştir.

Çocukların mizaç özellikleri günümüzde de en çok merak edilen konulardan birisidir. Yurt dışında mizaç ile ilgili kimi çalışmalar bulunmasına rağmen ülkemizde mizaç ile ilgili yapılan çalışmaların sınırlı sayıda olması dikkat çekmektedir. Yapılan çalışmalar incelendiğinde ise sıklıkla yetişkinlerin kişilik özelliklerine odaklanıldığı, çocukların mizaç özelliklerinin çok fazla araştırılmadığı belirlenmiştir. Özellikle ebeveynlerin kişilik özelliklerinin çocuğun mizacına etkileri ile ilgili ülkemizde yapılmış çok fazla çalışmaya rastlanmamıştır. Bu nedenle bu çalışmada annelerin kişilik özellikleri ve çocukların mizaçlarını etkileyen değişkenlerin 
belirlenmesi ve annenin kişiliği ile çocukların mizaçları arasındaki ilişkinin incelenmesi amaçlanmıştır.

\section{Materyal ve Metod}

\subsection{Araștırmanın Modeli}

Araştırma Ankara ili Sincan ilçesinde bulunan toplam beş özel anaokuluna devam eden 4-5 yaş arasında çocuğu olan annelerin kişilik özellikleri ile çocukların mizaçlarını etkileyen değişkenlerin belirlenmesi ve annenin kişiliği ile çocukların mizaçları arasındaki ilişkinin incelenmesi amacıyla tanımlayıcı olarak yapılmıştır.

\subsection{Araştırmanın Çalışma Grubu}

Araştırmaya Ankara ili Sincan ilçesinde bulunan toplam beş özel anaokuluna devam eden 4-5 yaş arasındaki çocukların anneleri dâhil edilmiştir. Araştırmada çalışma grubunun tümüne ulaşılmaya çalışılmış ve gönüllülük esas alınmıştır. Bu doğrultuda araştırmaya gönüllü olarak katılmayı kabul eden toplam 110 anne araştırmanın çalışma grubunu oluşturmuştur.

\subsection{Araştırmanın Veri Toplama Araçları}

Araştırmada veri toplama aracı olarak araştırmacı tarafından hazırlanan "Genel Bilgi Formu" , "Çocuklar İçin Kısa Mizaç Ölçeği" ve "Sıfatlara Dayalı Kişilik Testi" kullanılmıştır.

Genel Bilgi Formu: çocuğun cinsiyeti, yaşı, doğum sırası, anaokuluna devam süresi, annenin yaşı, sahip olduğu çocuk sayısı ve öğrenim durumuna ilişkin sorulardan oluşmaktadır.

Çocuklar için Kısa Mizaç Ölçeği: Ölçek Prior, Sanson ve Oberklaid (1989) tarafından geliştirilmiş, Yağmurlu ve Sanson (2004) tarafından Türkçe'ye uyarlamıştır. Çocuğun mizaç özelliklerini ölçmeye yönelik birden (hemen hiç) altıya (hemen her zaman) doğru seçenekleri olan altı dereceli likert tipi bir ölçektir. 30 maddeden oluşan ölçeğin tepkisellik, sebatkârlık, sıcakkanlılık ve ritmiklik olmak üzere dört alt boyutu bulunmaktadır. Tepkisellik boyutu çocuğun belirli bir uyaran veya olaya tepki vermeye hazır olma durumunu, sebatkârlık boyutu çocuğun dikkatini bir etkinlik üzerinde yoğunlaştırabilme durumunu, sıcakkanlılık-utangaçlık boyutu çocuğun yeni insan ve ortamlara yaklaşma eğiliminin olup olmadığını, ritmiklik boyutu ise çocuğun herhangi bir fonksiyonunun (uyku, açlık, tuvalet) zaman içerisindeki düzenliliğini ölçmektedir. Ölçeğin iç tutarlık 
puanları sıcakkanlılık için .80, tepkisellik için .77, sebatkarlık için.76 ve ritmiklik için .48 olarak bulunmuştur. Ölçek Baydar, Küntay, GökĢen, Yağmurlu ve Cemalcılar (2008) tarafından tekrar gözden geçirilmiş bu çalışmada iç tutarlık puanları sıcakkanlılık için .81, tepkisellik için .87, sebatkarlık için .88 ve ritmiklik için .61 bulunmuştur.

Sıfatlara Dayalı Kişilik Testi: Bacanll, İlhan ve Aslan (2009) tarafından geliştirilmiştir. Ölçek dişadönüklük, yumuşak başlılık, sorumluluk, duygusal dengesizlik ve deneyime açıklı olmak üzere beş alt boyuttan oluşmaktadır. Ölçeğin uyum geçerliğini sınamak için Sosyotropi Ölçeği, Çatışmalara Tepki Ölçeği, Negatif-Pozitif Duygu Ölçeği, Sürekli Kaygı Envanteri kullanılmıştır. Genel olarak incelendiğinde, ölçeğin boyutlarının uyum geçerliği için kullanılan ölçeklerle orta düzeyde ve anlamlı bir yapı ortaya koyduğu ve bu sonuçların uyum geçerliği açısından önemli olduğu bulunmuştur. Ölçeğin yapı geçerliğine ilişkin yapılan faktör analizinde elde edilen beş boyutun, kişiliğe ait varyansın \%52,6'sını açıkladığı belirlenmiştir. Ölçeğin güvenirliği için hesaplanan iç tutarlık katsayılarının .73 ile .89 aralığında değiştiği ve en yüksek iç tutarlık katsayısının Dışadönüklük (.89), en düşük iç tutarlık katsayısının ise Duygusal Dengesizlik (.73) boyutuna ait olduğu bulunmuştur.

\subsection{Verilerin Toplanması}

Araştırma için öncelikle Ankara ili Sincan ilçesinde bulunan toplam sekiz özel anaokulu yöneticileri ile görüşülmüş, araştırma hakkında bilgi verilmiş ve araştırma yapmamıza izin veren toplam beş özel anaokulu yöneticisinden sözlü olarak gerekli izin alınmıştır. Daha sonra araştırma hakkında kurumda görevli öğretmenlere bilgi verilmiş ve öğretmenler aracılığıyla veri toplama araçları annelere ulaştırılmıştır. Gönüllü olarak araştırmaya katılmayı kabul eden ve veri toplama araçlarını dolduran toplam 110 anne araştırmanın çalışma grubunu oluşturmuştur. Araştırmanın verileri Haziran 2013-Temmuz 2013 tarihleri arasında toplanmiştır.

\subsection{Verilerin Analizi}

Araştırmada homojen dağglım gösteren veriler için "t-Testi", "Tek Yönlü Varyans Analizi", homojen dağılım göstermeyen veriler için "MannWhitney U testi", "Kruskall Wallis Testi" ve annenin mizacı ile çocuğun mizacı arasındaki ilişkiyi incelemek için de "Pearson Korelâsyon Katsayısı Önemlilik Testi" kullanılmıştır. 


\section{Bulgular}

Araştırmaya alınan anne ve çocuklarının demografik özelliklerine ilişkin dağılımlar Tablo 1'de verilmiştir.

Tablo 1: Araştırmaya alınan anne ve çocuklarının demografik özelliklerine göre dağılımı

\begin{tabular}{|l|c|c|}
\hline Demografik Özellikler & $\mathbf{n}$ & $\mathbf{\%}$ \\
\hline Anne yaş & & \\
19- 35 yaş arası & 74 & 67.3 \\
36 yaş ve üzeri & 36 & 32.7 \\
\hline Anne öğrenim durumu & 29 & 26.4 \\
İlkokul & 20 & 18.2 \\
Ortaokul & 40 & 36.4 \\
Lise & 21 & 19.1 \\
Üniversite & & \\
\hline Sahip olduğu çocuk sayısı & 42 & 38.2 \\
Tek çocuk & 52 & 47.3 \\
2 çocuk & 16 & 14.5 \\
3̧ocuk ve üzeri & & \\
\hline Çocuğun cinsiyeti & 47 & 42.7 \\
Kız & 63 & 57.3 \\
Erkek & & \\
Çocuğun yaşı & 47 & 42.7 \\
4 yaş & 63 & 57.3 \\
\hline yaş & & \\
Çocuğun doğum sırası & 53 & 48.2 \\
İlk & 15 & 13.6 \\
Orta & 42 & 38.2 \\
Son & & \\
\hline Anaokuluna devam süresi & 60 & 54.5 \\
1 ay-12 ay & 50 & 45.5 \\
13 ay ve üzeri & $\mathbf{1 1 0}$ & $\mathbf{1 0 0}$ \\
\hline Toplam & & \\
\hline
\end{tabular}


Tablo 2: Çocukların Cinsiyetlerine Göre Mizaçlarına İlişkin Puan Ortalamaları, Standart Sapmalar ve t-Testi Sonuçları

\begin{tabular}{|c|c|c|c|c|c|c|c|c|}
\hline \multirow{2}{*}{$\begin{array}{l}\text { Mizaç alt } \\
\text { boyutları } \\
\text { Çocuğun } \\
\text { Cinsiyeti }\end{array}$} & \multicolumn{2}{|c|}{ Tepkisellik } & \multicolumn{2}{|c|}{ Sebatkarlık } & \multicolumn{2}{|c|}{ Sicakkanlılık } & \multicolumn{2}{|c|}{ Ritmiklik } \\
\hline & $X$ & $\mathrm{~S}$ & $X$ & S & $x$ & $\mathrm{~S}$ & $x$ & $\mathrm{~S}$ \\
\hline $\mathrm{K}_{12}$ & $\begin{array}{ll}47 & 27.89\end{array}$ & 6.74 & 25.42 & 6.89 & 26.23 & 6.56 & 27.04 & 5.29 \\
\hline Erkek & $63 \quad 27.42$ & 7.14 & 23.38 & 7.50 & 25.85 & 6.74 & 25.55 & 5.81 \\
\hline t-Testi Sonuçları & $\begin{array}{lc}S d & t \\
108 & .349\end{array}$ & $\begin{array}{c}\mathrm{p} \\
.728\end{array}$ & $\begin{array}{r}\mathrm{t} \\
1.48\end{array}$ & $\begin{array}{c}\mathrm{p} \\
.14\end{array}$ & $\begin{array}{c}\mathrm{t} \\
.294\end{array}$ & $\begin{array}{l}\mathrm{p} \\
.769\end{array}$ & $\begin{array}{c}\mathrm{t} \\
1.397\end{array}$ & $\begin{array}{c}\mathrm{p} \\
.165\end{array}$ \\
\hline
\end{tabular}

Tablo 2 incelendiğinde çocukların cinsiyetlerine göre mizaç ölçeğinin alt boyutlarından aldıkları puan ortalamaları arasında anlamlı bir farklılık olmadığı saptanmıştır ( $>$ >05). Ancak puan ortalamaları karşılaştırıldığında kız çocukların tepkisellik boyutu dışında diğer tüm boyutlarda erkek çocuklardan daha yüksek puan ortalamasına sahip olduğu belirlenmiştir.

Tablo 3: Çocukların Doğum Sırasına Göre Mizaçlarına İlişkin Puan Ortalamaları, Standart Sapmalar ve Varyans Analizi Sonuçları

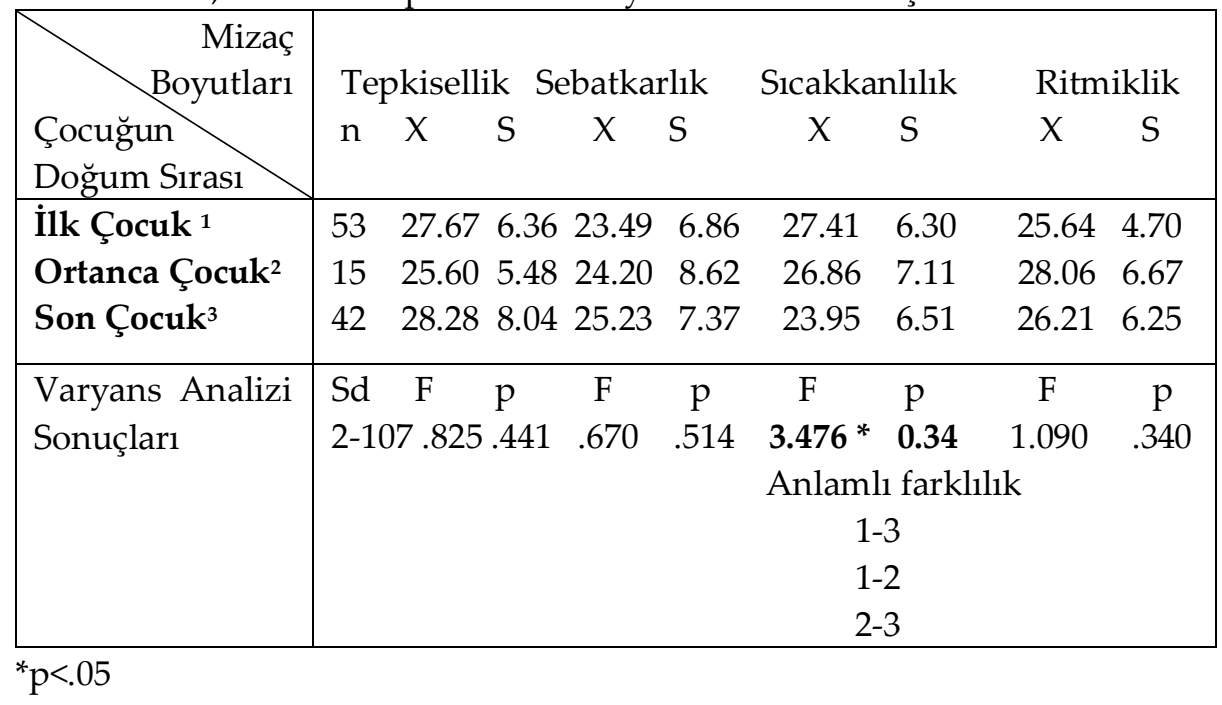

Tablo 3'de çocukların doğum sırasına göre mizaç puan ortalamaları incelendiğinde tepkisellik, sebatkârlık boyutunda son çocukların, ritmiklik boyutunda ortanca çocukların, sıcaklık boyutunda ise ilk çocukların en 
yüksek puan ortalamasına sahip olduğu görülmektedir. Ancak yapılan varyans analizi sonucunda doğum sirasının sadece sicakkanlılık boyutundan alınan puanlarda anlamlı farklılığa neden olduğu belirlenmiştir $(\mathrm{F}(2-107)=3.476, \mathrm{p}<.05)$. Elde edilen bu sonuç 1şığında, ilk çocukların ortanca ve son çocuklara göre daha sıcakkanlı olduğunu söylemek mümkündür. Scheffe testi sonuçları da; sıcakkanlılık boyutu açısından, ilk çocuklarla ortanca ve son çocuklar, ortanca çocuklar ile son çocukların puanları arasındaki farkın anlamlı olduğunu göstermiştir.

Tablo 4: Annelerin Yaşına Göre Mann-Whitney U Testi Sonucu

\begin{tabular}{|c|c|c|c|c|c|}
\hline \multirow{2}{*}{$\begin{array}{l}\text { Annenin yaşı } \\
\text { Nevrotizm } \\
19-35 \text { yaş } \\
36 \text { yaş ve üzeri }\end{array}$} & \multicolumn{2}{|c|}{ n Siralar Ortalaması } & Siralar To & lamı & $\mathrm{p}$ \\
\hline & $\begin{array}{l}74 \\
36\end{array}$ & $\begin{array}{l}53.33 \\
59.96\end{array}$ & $\begin{array}{l}3946.50 \\
2158.50\end{array}$ & 1171.500 & .306 \\
\hline $\begin{array}{l}\text { Dişadönüklük } \\
\text { 19-35 yaş } \\
36 \text { yaş ve üzeri }\end{array}$ & $\begin{array}{l}74 \\
36\end{array}$ & $\begin{array}{l}59.73 \\
46.81\end{array}$ & $\begin{array}{l}4420.00 \\
1685.00\end{array}$ & 1019.000 * & .046 \\
\hline $\begin{array}{l}\text { Deneyime Açıklık } \\
19-35 \text { yaş } \\
36 \text { yaş ve üzeri }\end{array}$ & $\begin{array}{l}74 \\
36 \\
\end{array}$ & $\begin{array}{l}58.14 \\
50.07 \\
\end{array}$ & $\begin{array}{l}4302.50 \\
1802.50 \\
\end{array}$ & 1136.500 & .213 \\
\hline $\begin{array}{l}\text { Yumuşakbaşlılık } \\
\text { 19-35 yaş } \\
36 \text { yaş ve üzeri }\end{array}$ & $\begin{array}{l}74 \\
36\end{array}$ & $\begin{array}{l}53.93 \\
58.74\end{array}$ & $\begin{array}{l}3990.50 \\
2114.50\end{array}$ & 1215.500 & .458 \\
\hline $\begin{array}{l}\text { Sorumluluk } \\
19-35 \text { yaş } \\
36 \text { yaş ve üzeri }\end{array}$ & $\begin{array}{l}74 \\
36\end{array}$ & $\begin{array}{l}58.04 \\
50.28\end{array}$ & $\begin{array}{l}4295.00 \\
1810.00\end{array}$ & 1144.000 & .231 \\
\hline
\end{tabular}

$\mathrm{p}<.05$

Tablo 4 incelendiğinde annelerin yaşlarına göre kişilik testinden aldıkları puan ortalamaları karşılaştıııldığında dışadönüklük boyutunda anlamlı bir farklılık olduğu görülmektedir ( $\mathrm{p}<.05)$. Yapılan Mann Whitney U-Testi sonucunda otuz altı yaşından daha küçük annelerin daha dışadönük olduğu belirlenmiştir (Dişadönüklük X=59.73). 
Tablo 5: Annelerin Öğrenim Düzeylerine Göre Kruskall Wallis Testi Sonucu

\begin{tabular}{|c|c|c|c|c|c|}
\hline $\begin{array}{l}\text { Annenin öğrenim } \\
\text { durumu }\end{array}$ & $\mathbf{n}$ & Siralar Ortalaması & sd & $\mathbf{X}^{2}$ & p \\
\hline \multicolumn{6}{|l|}{ Nevrotizm } \\
\hline İlkokul & 29 & 62.59 & 3 & 2.887 & .409 \\
\hline Ortaokul & 20 & 58.62 & & & \\
\hline Lise & 40 & 52.04 & & & \\
\hline Üniversite & 21 & 49.33 & & & \\
\hline \multicolumn{6}{|l|}{ Dışadönüklük } \\
\hline İlkokul & 29 & 50.90 & 3 & 7.123 & .068 \\
\hline Ortaokul & 20 & 42.25 & & & \\
\hline Lise & 40 & 59.95 & & & \\
\hline Üniversite & 21 & 66.00 & & & \\
\hline \multicolumn{6}{|l|}{ Deneyime Açıklık } \\
\hline İlkokul & 29 & 42.72 & 3 & $13.104^{*}$ & .004 \\
\hline Ortaokul & 20 & 44.24 & & & \\
\hline Lise & 40 & 62.39 & & & \\
\hline Üniversite & 21 & 66.00 & & & \\
\hline \multicolumn{6}{|l|}{ Yumuşakbaşlılık } \\
\hline İlkokul & 29 & 52.95 & 3 & 4.330 & .228 \\
\hline Ortaokul & 20 & 44.02 & & & \\
\hline Lise & 40 & 59.71 & & & \\
\hline Üniversite & 21 & 61.93 & & & \\
\hline \multicolumn{6}{|l|}{ Sorumluluk } \\
\hline İlkokul & 26 & 52.26 & 3 & $12.523^{*}$ & .006 \\
\hline Ortaokul & 20 & 35.62 & & & \\
\hline Lise & 40 & 61.39 & & & \\
\hline Üniversite & 21 & 67.69 & & & \\
\hline
\end{tabular}

$\mathrm{P}<.05$

Annelerin öğrenim durumuna göre kişilik testinden aldıkları puan ortalamaları incelendiğinde deneyime açıklık ve sorumluluk alt boyutlarında anlamlı bir farklılığın $(p<.05)$ olduğu, üniversite mezunu annelerin daha deneyime daha açık ve sorumluluk sahibi oldukları belirlenmiştir. 
Tablo 6: Çocuklar için Kısa Mizaç Ölçeğinin Alt Boyutları ile Sıfatlara Dayalı Kişilik Testinin Alt Boyutlarına İlişkin Pearson Korelâsyon Katsayısı Önemlilik Testi Sonuçları

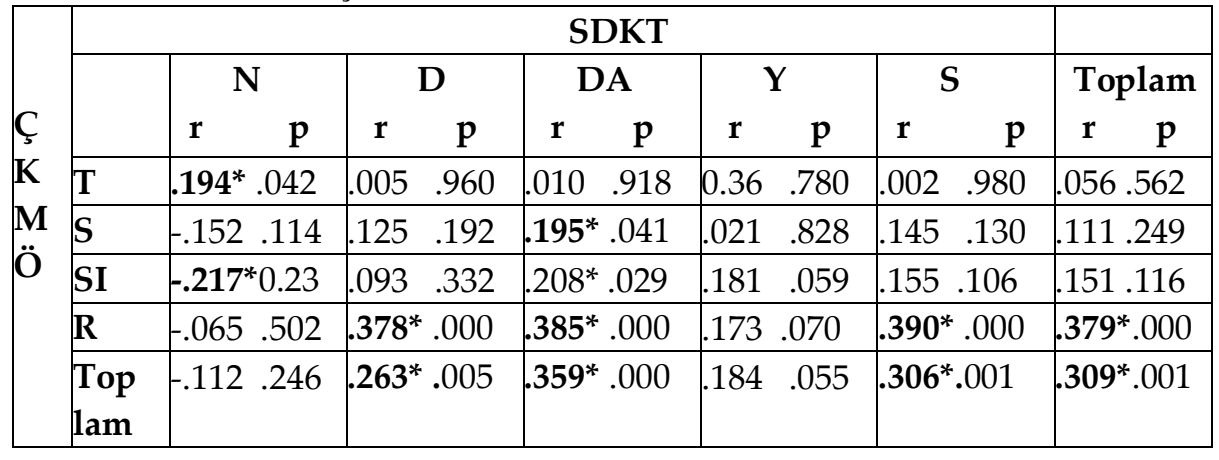

Tablo 6 incelendiğinde Sıfatlara Dayalı Kişilik Testi'nin (SDKT) nevrotizm (N) boyutu ile Çocuklar için Kısa Mizaç Ölçeği'nin (ÇKMÖ) tepkisellik $(\mathrm{T})$ boyutundan alınan puanlar arasındaki ilişkinin pozitif yönde $(\mathrm{r}=.194, \mathrm{p}<.05)$, sicakkanlılık (SI) boyutundan alınan puanlar arasındaki ilişkinin negatif yönde anlamlı $(\mathrm{r}=-2,17, \mathrm{p}<, 05)$, diğer alt boyutlar arasındaki ilişkinin ise anlamlı olmadığı ( $>$ >05), Sıfatlara Dayalı Kişilik Testinin dışadönüklük (D) boyutu ile Çocuklar için Kısa Mizaç Ölçeği'nin (ritmiklik (R) boyutundan alınan puanlar arasındaki ilişkinin pozitif yönde anlamlı $(\mathrm{r}=.378, \mathrm{p}<.05)$, diğer alt boyutlar arasındaki ilişkinin ise anlamlı olmadığ 1 (p>.05), Sıfatlara Dayalı Kişilik Testinin deneyime açıklık boyutu (DA) ile Çocuklar için Kısa Mizaç Ölçeği'nin sebatkârlık (S) ve ritmiklik (R) boyutlarından alınan puanlar arasındaki ilişkinin pozitif yönde anlamlı $(\mathrm{r}=.195, \mathrm{p}<.05 ; \mathrm{r}=385, \mathrm{p}<.05)$, diğer alt boyutlar arasındaki ilişkinin ise anlamlı olmadığ 1 ( $\mathrm{p}>$.05), Sıfatlara Dayalı Kişilik Testinin yumuşak başlılık (Y) alt boyutu ile Çocuklar için Kısa Mizaç Ölçeğinin alt boyutları arasındaki ilişkinin anlamlı olmadığı (p>.05), Sıfatlara Dayalı Kişilik Testinin sorumluluk (S) boyutu ile Çocuklar için Kısa Mizaç Ölçeği'nin ritmiklik (R) boyutundan alınan puanlar arasındaki ilişkinin pozitif yönde anlamlı $(\mathrm{r}=.390$, $\mathrm{p}<.05$ ) olduğu belirlenmiştir. Kısa Mizaç Ölçeğinden alınan toplam puan ile Sıfatlara Dayalı Kişilik Testinden alınan toplam puan arasındaki ilişki incelendiğinde ise orta düzeyde pozitif ve anlamlı bir ilişki olduğu bulunmuştur. 


\section{Tartışma, Sonuç ve Öneriler}

Anne kişiliği ve çocuğun mizacının incelendiği çalışmada çocukların mizaçlarında cinsiyet değişkeninin etkisine bakıldığında; kız çocukların tepkisellik boyutu dişında diğer tüm boyutlarda erkek çocuklarına göre daha yüksek puan ortalamasına sahip olduğu dikkat çekmektedir. Kız ve erkek çocuklar kendilerinden beklenen roller gereği farklı yetiştirilmektedir. (Yağmurlu ve ark. 2005). Kız çocuklarından erkek çocuklara oranla daha sebatkâr ve daha düzenli olmaları beklendiği için puan tepkisellik boyutu dışında diğer tüm boyutlarda puan ortalamaları yüksek çıkmış olabilir. Ancak yapılan t-testi sonucunda cinsiyet değişkeninin çocukların mizaçlarında anlamlı bir farklılık yaratmadığı saptanmıştır (p>.05). Ancak, Bryan ve Dix (2009) ise annelerin davranışsal desteklerinin çocuk mizacına etkisini inceledikleri çalışmalarında cinsiyet değişkenini anlamlı bulmuşlardır. Bu sonucun $\mathrm{kız}$ ve erkek çocuk yetiştirmede kültürel farklılıklar olmasında kaynaklandığı düşünülmektedir.

Araştırmada çocuğun doğum sırasının sicakkanlılık boyutundan alınan puanlarda anlamlı farklılığa neden olduğu belirlenmiştir $(\mathrm{F}(2-107)=$ $3.476, \mathrm{p}<.05)$. Bu sonuca göre ilk sırada doğan çocukların daha sıcakkanlı olduğu söylenebilir. Anne-babalar ilk çocuklarına anne-babalığa geçişin heyecanı ile daha fazla ilgi gösterebilmekte, daha fazla iletişime girebilmekte ve çocuklarına daha sosyal bir hayat sunabilmektedir (Grist ve McCor, 2010). Bu nedenle ilk çocukların sıcakkanlılık boyutundan aldıkları puanlar daha yüksek çıkmış olabilir.

Annelerin kişilik özelliklerinde annenin yaşının dışadönüklük boyutundan alınan puanlarda anlamlı farklılığa neden olduğu belirlenmiştir $(\mathrm{p}<.05)$. Dışadönüklük boyutu sosyallik, sevecenlik, arkadaş canlısı olma, konuşkan olma, girişken ve iddialı olma, dış dünyaya açık olma ile tanımlanmaktadır (Arsan, 2010). Anneler ilerleyen yaşla birlikte çocukların da büyümesiyle kendilerine daha fazla zaman ayırmak isteyebilmekte ve sakin bir hayatı tercih edebilmektedir. Daha genç anneler ise aile dışındaki aktivitelere daha fazla zaman ayırabilmekte yaşları ve konumları gereği daha fazla insanla iletişime girebilmekte ve daha sosyal olmayı tercih edebilmektedir (Kaya, 2010). Vapur da (2006) 3-6 yaş arası çocuğu olan ebeveynlerin kişilik özellikleri ile anne-baba tutumlarının bazı değişkenlere göre incelenmesi adlı çalışmasında annelerin kişilik özellikleri ile yaşları arasında anlamlı bir farklılık bulmuştur.

Araştırmada annelerin öğrenim düzeyinin deneyime açıklık ve sorumluluk alt boyutlarından alınan puanlarda anlamlı farklılığa neden olduğu belirlenmiştir $(p<.05)$. Bu sonuca göre annelerin öğrenim düzeyleri 
yükseldikçe daha fazla deneyime açık ve sorumluluk duygusu yüksek bir kişilik özelliğine sahip oldukları söylenebilir. Öğrenim düzeyi yükseldikçe anneler daha bilinçli olmakta, sorumluluk almaktan kaçmamakta, deneyime ve yeniliğe daha açık olmaktadır (Durmuş, 2006). Bellibaş ve ark. (2009) da ayrılma anksiyetesi bozukluğu olan okul öncesi yaş grubu çocukların annelerinin mizaç özellikleri adlı çalışmalarında annenin öğrenim düzeyi açısından, hasta ve kontrol grupları arasında anlamlı fark bulmuşlardır.

Sıfatlara Dayalı Kişilik Testi'nin nevrotizm boyutu ile Çocuklar için Kısa Mizaç Ölçeği'nin tepkisellik boyutundan alınan puanlar arasındaki ilişkinin pozitif yönde $(\mathrm{r}=.194, \mathrm{p}<.05)$, sıcakkanlılık boyutundan alınan puanlar arasındaki ilişkinin negatif yönde anlamlı $(\mathrm{r}=-2,17, \mathrm{p}<, 05)$ belirlenmiştir. Bu bulgulara göre nevrotik (duygusal dengesizlik) özelliği olan annelerin çocuklarının daha tepkisel olduğu ve daha az sıcakkanlı olduğu söylenebilir. Duygusal açıdan dengesiz bireyler olumsuz duygu ve düşüncelere daha fazla sahip bireylerdir. $\mathrm{Bu}$ duygular ve düşünceler annelerin yıkıcı davranışlar sergilemelerine ve dolayısıyla duygusal açıdan dengesizlikler yaşamasına neden olmaktadır. Nevrotik özelliğe sahip anneler davranışlarıyla çocuklarına olumsuz model oluşturmaktadır. Bu durumda çocukları etkileyebilmekte, insanlara ve olaylara daha fazla tepki göstermelerine ve kendi iç dünyalarına kapanmalarına neden olabilmektedir (Güler, 2007). Türkbay ve Söhmen (2001) çalışmalarında annesi nevrotik kişilik özelliğine sahip çocukların daha sık ruhsal sorunlar yaşadıklarını ve daha sosyofobik davranışlar sergilediklerini belirlemişlerdir.

Sıfatlara Dayalı Kişilik Testinin dişadönüklük boyutu ile Çocuklar için Kısa Mizaç Ölçeği'nin ritmiklik boyutundan alınan puanlar arasındaki ilişkinin pozitif yönde anlamlı $(\mathrm{r}=.378, \mathrm{p}<.05)$ olduğu belirlenmiştir. Ritmiklik boyutu çocuğun uyku, yemek, tuvalet gibi konulardaki düzenliliğini ifade etmektedir (Yağmurlu ve ark. 2005). Dışa dönük anneler ev dışında da zaman geçirmek istedikleri için ev ve çocukla ilgili rutin faaliyetleri belirli bir düzen içerisinde yapmak isteyebilir ve çocuklarını da bu konuda yönlendirebilir. Her gün aynı saatte yemek yiyen ve uyuyan çocukta zaman içerisinde bunu alışkanlık haline getirebilir ve öz bakım becerileri vb. konularda ritmik özellik gösterebilir.

Sıfatlara Dayalı Kişilik Testinin deneyime açıklık boyutu ile Çocuklar için Kısa Mizaç Ölçeği'nin sebatkârlık ve ritmiklik boyutlarından alınan puanlar arasındaki ilişkinin pozitif yönde anlamlı ( $\mathrm{r}=.195, \mathrm{p}<.05 ; \mathrm{r}=385$, $\mathrm{p}<.05)$ olduğu bulunmuştur. Bu sonuca göre annesi yeni durumlara daha açık olan çocukların daha sebatkâr ve daha ritmik olduğu söylenebilir. 
Sebatkârlık boyutu, çocuğun dikkatini bir etkinlik üzerinde yoğunlaştırabilme durumunu ifade etmektedir (Ummanel, 2007). Deneyime açık anneler meraklı, yaratıcı, bağımsız, , kendine özgü, hayal gücü kuvvetli, ilgileri geniş, cesur, değişikliği seven, estetik bakış açısı olan, sanatsal düşünen, doğal, özgür düşünceli, açık fikirli, çocukları ile ilgili konularda geleneksel olmayan kişilerdir (Eryılmaz ve Ercan, 2011). Bu nedenle bu özelliğe sahip annelerin çocuklarının da meraklı, dikkati kolayca dağılmayan daha sabırlı çocuklar olduğu düşünülmektedir.

Sıfatlara Dayalı Kişilik Testinin yumuşak başlılık alt boyutu ile Çocuklar için Kısa Mizaç Ölçeğinin alt boyutları arasındaki ilişkinin anlamlı olmadı $\breve{g} 1$ ( $>$ >05) belirlenmiştir.

Sıfatlara Dayalı Kişilik Testinin sorumluluk boyutu ile Çocuklar için Kısa Mizaç Ölçeği'nin ritmiklik boyutundan alınan puanlar arasındaki ilişkinin pozitif yönde anlamlı $(\mathrm{r}=.390, \mathrm{p}<.05)$ olduğu belirlenmiştir. $\mathrm{Bu}$ sonuca göre sorumluluk sahibi annelerin çocuklarının daha ritmik olduğu söylenebilir. Sorumluluk sahibi anneler amacı olan, kararlı, tedbirli, kurallara bağlı, titiz, çalışkan, işlerini ve yapması gerekenleri iyi organize eden düzenli kişilerdir (Güler, 2007). Bu kişiler çocukları ile ilgili konularda da titiz ve düzenli oldukları için çocukların ritmiklik özelliği yüksek çıkmış olabilir.

Çocuk mizaç toplam puanı ile anne mizaç toplam puanı arasındaki ilişki incelendiğinde ise çocuğun toplam mizacı ile annenin toplam mizacı arasında orta düzeyde pozitif ve anlamlı bir ilişki olduğu bulunmuştur. Bu sonuca göre annenin kişilik özelliği olumlu yönde arttıkça çocuğun mizacı da olumlu yönde artış göstermektedir. Kişiliğin parçası olan mizacın gelişiminde kalıtım söz konusu olduğu için annelerin kişilik özellikleri ile çocukların mizaçları arasında ilişki olması beklenen bir sonuçtur.

Araştırmadan elde edilen bulgular sonucunda ebeveynlerin olumsuz kişilik özelliklerinin çocuğun mizaç ve ruhsal sağllğındaki yeri tartışılarak risk etkenlerinin önemi, anne-baba eğitimlerinde vurgulanabilir. Olumsuz mizaç özelliğine sahip çocukların yaşayacağı uyum sorunlarının azaltılması için uygun davranış yöntemleri geliştirilebilir. Olumsuz mizaçlı çocuğu olan veya olumsuz kişilik özelliğine sahip ebeveynler için danışmanlık hizmetleri verilebilir. Kişilik özelliklerine karşı bireylerin farkındalıklarını arttıracak, davranış değiştirme ve başa çıkma stratejilerini de kapsayacak yapılandırılmış programlar hazırlanabilir. Bu araştırmada değişken sayısı sınırlı tutulmuştur. Annelerin ve çocukların mizaçları farklı değişkenler açısından da değerlendirilebilir. Bu çalışmada dikkati çeken bir diğer nokta çocuk ve yetişkinler için mizaç ölçme araçlarının sınırlı sayıda bulunmasıdır. Bu nedenle özellikle okul öncesi dönemdeki çocukların 
mizaçlarını değerlendirmeye yönelik ölçek geliştirme çalıştırmaları veya yurt dişından ölçek uyarlama çalışmaları yapılabilir.

\section{Kaynakça}

Altıntaş, İ. (2009). Ayrılma Anksiyetesi Tanısı Alan Çocukların Ebeveynlerinin Mizaç ve Karakter Özellikleri. Yayımlanmamış yüksek lisans tezi, Ege Üniversitesi Sosyal Bilimler Enstitüsü, İzmir.

Arsan, H. (2010). Algilanan Ebeveyn Kabul ve Reddinin Mizaç ve Karakter Özelliklerine Etkisi. Yayınlanmamış yüksek lisans tezi, Ege Üniversitesi Sosyal Bilimler Enstitüsü, İzmir.

Bellibaş, S., Erermiş, S.,, Özbaran. B., Demiral .N., Altıntoprak.E. ve Bildik. T. (2009). Ayrılma Anksiyetesi Bozukluğu Olan Okul Öncesi Yaş Grubu Çocukların Annelerinin Mizaç Özellikleri. Türk Psikiyatri Dergisi, 20(1); 14-21.

Bryan, A. ve Dix.T. (2009). Mothers' Emotions and Behavioral Support During Interactions with Toddlers: The Role of Child Temperament. Social Development, $18 ; 3$.

Durmuş. R. (2006). 3-6 yaş Arası Çocuğu Olan Ebeveynlerin Kişilik Özellikleri ile Anne Baba Tutumlarının Bazı Değişkenlere Göre İncelenmesi. Yayınlanmamış yüksek lisans tezi, Marmara Üniversitesi Eğitim Bilimleri Enstitüsü, İstanbul.

Eryılmaz, A. ve Ercan, L. (2011). Öznel İyi Oluşun Cinsiyet, Yaş Grupları ve Kişilik Özellikleri Açısından İncelenmesi. Türk Psikolojik Danışma ve Rehberlik Dergisi, 4(36); 139-151.

Güler, M. (2007). Kuşaklararası Annelik Bilişleri, Kişilik Özellikleri, Yaşam Doyumu ve Çocuk Yetiştirme Hedefleri. Yayınlanmamış yüksek lisans tezi, Mersin Üniversitesi Sosyal Bilimler Enstitüsü, Mersin.

Grist, C. ve McCor, D.(2010). Individual Differences in Preschool Children: Temperament or Personality. Child Development, 19: 264-274.

Katainen, S., Raikkönen, K. ve Jarvinen, K. (1998). Development of Temperament: Childhood Temperament and the Mother's Childrearing Attitudes as Predictors of Adolescent Temperament in a 9-Year Follow-Up Study. Journal of Research Adolescence, 8(4); 485509.

Kaya, A. (2010).illköğretim Öğrencilerinden Anne-Babalarının Çocuk Yetiştirme Tutumlarının Kişilik Özelliklerine Göre Değişkenliğin İncelenmesi. 
Yayınlanmamış yüksek lisans tezi, Maltepe Üniversitesi Sosyal Bilimler Enstitüsü, İstanbul.

Muris, P. ve Ollendick, T. (2005). The Role of Temperament in the Etiology of Child Psychopathology. Clinical Child and Family Psychology Review, 8(4), 271-289.

Neal. R., Meyer.J. ve Pomares.Y. (2007). Infant Joint Attention, Temperament, and Social Competence in Preschool Children. Child Development, 78(1), 5369.

Öç, Ö., Şişmanlar, Ş., Ağaoğlu, B., Tural, Ü., Öner, E., Karakaya, I. (2006). Anne-Babalarında Ruhsal Bozukluk Olan Çocukların Ruhsal Durumlarının Değerlendirilmesi. Psikiyatri Dergisi, 9; 123-130

Şahinoğlu.N. (2010). Tükenmişlik Sendromu İle Mizaç ve Karakter Boyutları Arasındaki İlişkiler. Yayınlanmamış yüksek lisans tezi, Ege Üniversitesi, Sosyal Bilimler Enstitüsü, İzmir.

Türkbay, T., \& Söhmen, T. (2001). Ayrılık kaygısı bozukluğunda bireysel ve ailesel etmenler. Çocuk ve Gençlik Ruh Sağhlğ̆ı Dergisi, 8 (2), 77-84.

Yağmurlu.N., Sanson.A. ve Köymen.B. (2005). Ebeveynlerin ve Çocuk Mizacının Olumlu Sosyal Davranış Gelişimine Etkileri: Zihin Kuramının Belirleyici Rolü. Türk Psikoloji Dergisi, 20(55), 1-20.

Yavuzer, H. (2006). Çocuk Psikolojisi, İstanbul: Remzi Kitapevi.

Yılmaz, K. (2010). Ebeveynlerin Kişilik Özelliklerinin Bazı Değişkenlere Göre Incelenmesi. Yayınlanmamış Yüksek lisans tezi, Selçuk Üniversitesi Sosyal Bilimler Enstitüsü, Konya.

Yörükoğlu, A. (2007). Gençlik Çağı Ruh Sağhlğı ve Ruhsal Sorunlar. İstanbul: Özgür Yayınları. 